\title{
ФОРМИРОВАНИЕ МУЖЧИНЫ В РАМКАХ ТРАДИЦИОННЫХ ПРЕДСТАВЛЕНИЙ О МУЖСКОМ ПУТИ «МОРТТУЙ» У КОМИ-ЗЫРЯН
}

\section{Ирина Ильина \& Олег Уляшев} ilina56@mail.ru \& oulyashev@mail.ru

\begin{abstract}
Аннотация: На протяжении веков охота и рыболовство были базисом традищионной культуры народа коми. Ещё в XIX-XX вв. они являлись основным видом хозяйственной деятельности для двух третей мужчин и в настоящее время продолжают определять доминанты этнического самосознания. В первую очередь, с промысловой деятельностью связано концептуальное для традиционной культуры коми представление о предназначении и жизненном пути мужчины (морттуй 'мужской путь, мужские способности'). Статья посвящена традиционному воспитанию мальчиков у народа коми, их становлению и вхождению в мужской мир, в мир промысловиков.
\end{abstract}

Ключевые слова: морттуй, аньтуй, чера-пурта морт, охотничий промысел, артель 


\section{К постановке проблемы}

Веками охота и рыболовство у коми были основным источником средств существования и фрундаментом, определяющим образ жизни, мировоззрение, культуру народа. Несмотря на постепенное снижение их роли в традиционной экономике, на Удоре, Печоре, в верховьях Выми и Вычегды охота и рыболовство ещё в начале XX в. оставались одним из основных видов хозяйственной деятельности для двух третей взрослого мужского населения, принося доход, превышающий 75\% выручки от всех промысловых занятий (Конаков 1983: 22-27). И в настоящее время они во многом определяют доминанты этнического самосознания, тем более что сельское население северных и восточных районов Республики Коми вновь возвращается к традиционным промыслам.

Именно с охотой, в первую очередь, связывалось концептуальное для традиционной культуры коми понятие о «мужском пути» - представление о предназначении и жизненном пути мужчины. Тяжёлый, но привычный и естественный для «настоящих мужчин» охотничий промысел, женщинами воспринимался как достаточно әкстремальный, поскольку был сопряжён с множеством тягот и опасностей. Среди них и выживание в суровых природных условиях, и состязание в хитрости и выносливости со зверем, и удалённость от населённых мест, а значит, отсутствие помощи со стороны, и большие физические и психологические нагрузки (напряжённое ожидание, необходимость жить в замкнутом мужском коллективе, отсутствие женщин и домашнего комфорта). $K$ тому же лес традиционно воспринимался как пространство, населённое лесными духами, духами-хозяевами мест и отдельных видов животных, которые ревностно охраняют права на свои владения и своих подопечных с мифических времён.

Судя по доминированию охотничьей тематики и образности в фольклорных текстах, охота у коми приравнивалась к военной службе, столь же достойной поэтизации и эпизации стороне мужской культуры. Охотничье-колдовской эпос коми, качественно и количественно доминирующий над героическим эпосом, указывает на особую важность для коми культуры промысловой сферы, поэтически сравнимой с эпическим «полем битвы», как 
область проявления сверхспособностей героя. И в других жанpax фольклора, и в повседневной речи образ охотника сильно поэтизирован и несёт положительную эмоционально-оценочную нагрузку, являясь эталоном "настоящего мужчинь», называемого вӧр кыцныци, вадор каля 'лесной ворон, прибрежная чайка'. Для волшебно-авантюрных коми сказок характерным переходным моментом является погружение героя-охотника в стихию леса, в отличие от выхода в «чисто поле» русского богатыря или «в синюю степь» - тюркских, алтайских, монгольских батыров.

Противниками богатыря коми, в первую очередь, становятся олицетворённые природные силы, или воплощения стихий, что, несомненно, является отражением реалий промысловой деятельности, сопряжённой с преодолением холода и непогоды, водных и горных преград, распутицы и глубокого снежного покрова, то есть всех неприятных сюрпризов, которые может преподнести суровая северная природа. Вероятно, поэтому в терминах, обозначающих охоту, охотника, добычу и лесных духов, семантический акцент ставится не на добывании зверя, а на освоении таёжного пространства и слиянии с тайгой: вӧральсь 'охотник' (букв. 'лесующий'), вӧравны 'охотиться' (букв. 'лесовать'), вӧрпа ‘зверь-дичь' (букв. 'лесное сообщество'), вӧрса 'леший' (букв. 'лесной, из леса'), вӧр олысь 'лесной человек-дух' (букв. 'лесной житель').

\section{Становление охотника}

Только что родившегося мальчика уже напутствовали в жизнь как на охотничью тропу, указывая в качестве образца для подражания кого-либо из старшего поколения в обращении к нему с благопожеланием: Ыджыд ай мында сял сет кыйсьыны 'Столько, сколько деду [было дано], дай умения охотиться'.

Как отмечает Николай Конаков, приобщаться к профессиональной охотничьей культуре коми мальчик начинал, едва начав говорить и понимать речь окружающих. Приобщение это шло в доступной ему развлекательно-игровой форме. Даже нос ребёнку вытирали под присказку с промысловой тематикой: Учи-кычи мыччыссяс, вит пон тшапкас 'Ласка [из норки] выглянет, пять собак тут же схватят'. Большое значение имели 
подчёркнуто уважительное отношение к хорошим промысловикам и престижность занятия охотой в глазах окружающих. Уже в колыбельных песнях ребёнку сообщалось, чем занят в это время его отец: Баю бай, папа твой в лес ушёл белок-рябчиков ловить, лисиц-зайцев стрелять. Мать или бабушка предрекали ему в песенной импровизации судьбу удачливого охотника: Пусть, как дед, будешь добытчик, однил выстрелол птииу роняющий! Этой же цели служили образы героев-промысловиков в фольклоре (в пословицах, поговорках и присказках), которые сопровождали ребёнка в обыденной жизни (Конаков 1994: 118-119).

С детства начинали и подготовку к мужскому образу жизни, развивая необходимые для промысловика качества. В первую очередь это касалось физической силы, выносливости и ловкости, которая приобреталась при выполнении домашних и хозяйственных работ. В отсутствие старших мужчин, мальчики 9-12 лет выполняли все мужские работы, а первый промысловой опыт приобретали, обихаживая свои промысловые путики вблизи поселений. Охотничьи навыки дети начинали приобретать с шести-семи лет, добывая мелкую птицу: клестов, снегирей, пуночек (полярных воробьёв) с помощью силков, сеток и других ловушек. Дети постарше осенью ловили боровую дичь силками, зимой силками же - куропаток, петлями, капканами и ловчими ямами - зайцев, проходя за день пешком или на лыжах десятки километров и готовя себя к будущим многодневным гонкам за лосем или соболем. В процессе традиционного воспитания закладывались такие психологические качества как терпение, уравновешенность, упорство, чувство коллективизма.

«По воспоминаниям одного из профессиональных коми охотников, Ивана Прокопьевича Федькова, в урожайный год добыча могла доходить до двух тысяч клестов. Вот как он описывает начало своего промыслового пути: «Я начал лесовать с семи лет, когда мне сшили первый зипун (дукӧс) из толстого сукна серой шерсти. Орудием лова были волосяные петли - дзуг. Первой «жертвой» моих охотничьих похождений был уркай (еловый клест). Через год-другой, научившись как следует управляться с клестами и устраивать всякие петли, я принялся уже за ловлю куропаток зимой, по прибрежным ивнякам и ракитникам на особые висячие петли - тройчатки, свитые из конского волоса. 
Когда мне был 10-й год, отец устроил мне пару подбитых лыж из елового дерева, с помощью которых я имел возможность ходить за куропатками всю зиму. К 14 годам отец смастерил ружье, и я начал ходить на дальние путики. $К 18$ годам я вполне мог заменить отца на дальних путиках, и на ближних охотах, и на глухариных токах» (Коми морт 1928: 81-82, цитировано по статье Панюков 2014: 149-150).

Дети, занимаясь самостоятельным промыслом, «приобретали и закрепляли практические навыки "взрослой» охоты, но - что более важно - именно здесь формировался фундамент традиционного, мужского мировоззрения. Это касается и основ промысловой этики, мифологии, экологии и магии, которые, хотя и были адаптированы "под детей», но отнюдь не в игровом ключе. И весьма показательно, что в детской промысловой практике активно использовались не только свой инструментарий, но и свои заговоры на дичь, составляющие особый пласт вербальной магии» (Панюков 2014: 146).

Промысловая практика и промысловая магия, в освоении которой закладывались мировоззренческие и поведенческие стереотипы, вводили мальчика, а затем и юношу, во взрослый мужской мир.

Четырнадцатилетнего подростка, проявившего своё умение и фризические данные, могли взять в охотничью артель, куда обычно брали одного смышлёного подростка, который в меру сил, выполнял общие обязанности, поскольку зіль мортльь мойыљ-низьыљ керка пельӧсас кайӧ 'трудолюбивому человеку бобр-соболь на угол дома забираются'. Разумеется, к «сынам артели» обычно относились бережно, но достаточно требовательно, в конце сезона выделяя им треть или половину от взрослого пая. В артельной охоте у юноши укреплялось тело, приобретались навыки работы с ловушками, знания повадок животных и изменений природы, формировался характер. На своём опыте и опыте сотоварищей юноша учился выживанию в тайге, налаживанию отношений с лесом, для чего необходимо было знание этических норм и правил, а в случае их нарушения - определённых ритуалов, целью которых было примирение с теми, против которых обернулось или могло обернуться нарушение. 


\section{Таёжный этикет и ритуальное поведение}

Особо важными считались ритуалы, оформлявшие выход на промысел и начало жизни в лесу. Одним из главных правил охотника было сохранение в тайне своих намерений, поэтому отправку в лес, особенно выход на крупного зверя, старались не афишировать, скрывая особенно от женщин и детей. Будущий руководитель артели обычно обходил охотников и иносказательно спрашивал: Мӧдӧдчи ӧтилаӧ ветльны да, тэ ветлан-он? 'Собрался я в одно место сходить, ты-то пойдёшь ли?'. Иногда заранее сговаривались два-три охотника и с этим же вопросом шли к более опытному, намеченному на роль хозяина артели. Специальными ритуалами человек, входящий в лес, изначально должен был настроиться и подготовить себя к особому существованию, отличному от домашнего. Для этого перед выходом на промысел мужчины должны были обязательно очиститься не столько от грязи телесной, сколько от ритуальной нечистоты пеж, связанной, прежде всего, с сексуальной сферой, для этого накануне обязательно парились в бане, объединяющей магию огня, воды, дерева, ветра и камня (Налимов 1991: 6-9). Перед дорогой надевали чистое бельё или же меняли одежду сразу по прибытии на первую стоянку.

Приметы, связанные с отправлением на промысел в основном совпадали с общими правилами выхода в дорогу:

Оз позь туйӧ петысьӧс кильчӧ вылӧдз, ььвлаӧдз колльӧдньь 'Нельзя провожать отправляющегося в путь до крыльца, на улицу';

Петтӧдзыс да сразу петӧлльсст джодж чыцкћьны оз позь: туйсӧ мунысьыссльсь чышкан 'Перед выходом и сразу после выхода пол подметать нельзя: следы путнику заметёшь (обратную дорогу не найдёт - npuл. aвm.)';

Туйӧ петьссьльсь нинӧл оз босьтны: деньга ни кӧлуй, весиг сунистор кӧ ӧшйӧма - оз позь босьтны: мьийкӧ оз cудзсьь туяс 'У выходящего в дорогу ничего не берут: ни 
денег, ни вещей, даже если ниточка прицепилась - нельзя убирать: недостанет чего-нибудь в пути';

Муньсьльь туй оз вожмавны 'Путнику дорогу не переходят' и т. д.

Охотничий промысел, как важная часть традиционной жизни коми, требовал соблюдения ритуальных и моральных предписаний не только охотником, но и его домашними. Если мужчины ушли на промысел, домашним запрещалось ругаться и шуметь, чтобы не распугать добычу и не вызвать ссору среди охотников. Наряду с этими существовали приметы и предписания, связанные только с охотой. Считалось неприличным спрашивать у отправляющегося охотника, куда он идёт, а у возвращающегося - сколько или что он добыл. На бестактные вопросы следовало отвечать уклончиво: Сiдз, тшак корсьны (турун видзӧдлььнь) maй мӧдi 'Так, грибы поискать (травостой или сено проверить) вот собрался'; Сідз тай ветлі вӧрсӧ видзӧдлььнь 'Да так, сходил лес посмотреть'. Не допускалось заранее упоминать про дичь, чтобы не вспугнуть удачу. Нельзя было показывать добычу, особенно черноволосым и черноглазым людям. В случае неудачи, любопытного могли обвинить и в преднамеренной порче.

Входя в лес или перед началом промысла делали подношения лешему или водяному: оставляли на пне (бросали в воду) табак, хлеб и другую снедь, исключая рыбники. Также широко практиковалось очищение огнём, которое проводили как при входе в лес, так и перед первым или очередным забросом невода. Вымские рыбаки с целью примирения с водяным духом (васа) разводили на берегу костёр, в который бросали кусочки стелек или лоскутки одежды, кусочек тины, вытащенной из воды, охапку хвороста, принесённого из леса. После произнесения заговора Васянь кӧ - ваӧ, вӧрсянь кӧ - вӧрӧ, лортсянь кӧ - биӧ 'Если из воды - в воду, если из леса - в лес, а если от человека в огонь' все перепрыгивали через костёр и обходили его три раза, проходя обязательно через дым. «Вишерские охотники перед повторным выходом на промысел разводили костёр из лучин у порога внутри дома и, уходя на охоту, перешагивали через него. Обычно обряд очищения проводился также перед началом промысла. На верхней Вычегде обряд совершался по прибытии 
на место охоты, перед началом промысла, а в с. Палевицы перед каждым забросом невода все участники рыболовной артели проходили через дым от веток можжевельника, брошенных в костёр» (Конаков 1994: 145).

В течение всего охотничьего сезона соблюдались правила, регламентирующие отношения с лесом, зверем, духами. Кроме жертвоприношений перед началом охоты, принято было оставлять на пне или на берегу первую добычу лесному или водяному духу, для лесного духа клали рядом осьмушку табака. На верхней Вычегде, поймав первую сёмгу, рыбаки выходили на берег, варили и съедали голову, только после этого забрасывали невод повторно. Убив лося, варили его язык и печень на месте. Добыв медведя, в первую очередь выбивали его клыки и отрезали когти, затем снимали шкуру, разрезали сердце крест-накрест, и отрезали голову. Голову медведя поднимали на дерево, нанизывали на кол и оставляли на месте добычи или закапывали мордой на восток со словами Со, вокӧ, тэнӧ увлань юрӧн дзебал, рыта-асылӧ банӧн, бӧр костӧл вылӧ 'Вот, брат, тебя зарываем вниз головой, лицом с запада на восток, чтобы сюда не возвращался'.

Существует также строгий запрет на ругань, сквернословие и тем более инвокацию нечистого в лесу, вопреки женскому высказыванию Гортын эн матькы, абу ӧд вӧрын 'В доме не матерись, не в лесу ведь'. Известны былички о том, как водяной разрывал сети артели, один из членов которых выругался после заброса невода. Считалось, что лесной дух может даже «выкинуть» из леса охотника-сквернослова (Конаков 1994: 145).

Ӧти кыцйсьысьь сӧтль понсӧ сетас да ещё на и ёрччас луннас ур кыйигас, сӧткас. Понйыс сэсся вошӧ. А войнас ноддя пестас да бисӧ лыддьӧдас да молитваяс льцддс, оз ло лӧсьыљ да. Войнас куимӧн локтасньь, ӧти, зэв ьцджьљ, сьӧд, шуӧ: босьтӧй пӧ. A найӧ кватитласны да кинысӧ
Один охотник сатане собаку отдал да ещё и сквернословил днём на белковании, Сатану поминал. Потом собака пропала. А ночью нодью разжёг и огонь отчитал, молитвы прочитал на огонь, потому что на душе нехорошо стало. Ночью трое пришли. Один, очень большой, чёрный говорит: «Забирайте». А они руки 
кыскыштӧны: "Кыцз нӧ пӧ босьтан, сотӧ да?» $К y$ илььсь тадзи. Сы бӧрын шуук! - мунаснь-лэбасньь. А мужикыдлӧн лядьвейяссьыс кыљ вежон лӧзбясьис оз бырны. Понйыс куили лун лысти локтас, няйтын тупльӧдлӧма, няйт шлак ставнас. ${ }^{1}$ протянут и отдёргивают: «Как его возьмёшь, если обжигает?» Трижды так. А после этого шуук! - улетели. У мужика с ляжек две недели синяки не пропадали. Собака через три дня вернулась, в грязи вываляна, как ком грязи.

Лесного духа можно было спровоцировать на встречу и непреднамеренно. Для этого достаточно было не спросить разрешения на ночлег у лесной избушки или ели, под которой устраивались. Считалось, что и избушка, и дерево имеют своих хранителей, которые берут под своё покровительство охотника, произнёсшего этикетную фразу: Керкаӧй, керкаӧй (козйӧй, козйӧй), лэдз войковтны, видз тӧльссь-падераьıсь, биылсь-ваььсь, лёк йӧзысь, лютӧй зверысь 'Избушка, избушка (ель, ель), пусти переночевать, обереги от ветра-naдеры, от огня-воды, от дурных людей, от лютого зверя'. В лесную избушку (даже в свою) нельзя было заходить без стука, а растопив печь, следовало кинуть в огонь кусочек хлеба. Существует множество быличек о том, что к дереву, под которым по всем правилам заночевал охотник, ночью приходит некий дух и приглашает ель на поминки (свадьбу); ель отказывается под тем предлогом, что у неё есть гости; утром, как только охотник отходит на безопасное расстояние, это дерево падает. Охотники опасались устраиваться на ночлег в нечистых местах, у развилки дорог и под развилистым деревом, считалось, что там проходит дорога духов-вихрей (свадебный поезд), которые могут прогнать человека или раскидать его нодью.

Поскольку, по представлениям коми, каждое дерево и каждый вид животных имеет своего «хозяина» или духа-хранителя, строго запрещались бессмысленная рубка деревьев и необоснованное убийство животных.

Считалось, что лесные духи могут наказать и за проступки, совершённые в лесу, но не связанные напрямую с охотой, поэтому охотник должен следить не только за окружающим, но 
и за своими мыслями и поступками, не забывая при этом об основной цели своего пребывания в лесу.

\section{Артельная охота}

Охотничий сезон у коми состоял из осенней охоты на боровую дичь и зимне-весенней на пушного и крупного зверя. И если осенняя охота (с Семёнова дня 14 сентября н. с. до Покрова 14 октября н. с.) проходила на охотничьих угодьях, находящихся относительно недалеко от поселений, и заключалась преимущественно в обходе промысловиком охотничьих путиков, то зимне-весенняя представляла собой артельный поход (нередко за Урал) за сотни километров в неблагоустроенные предварительно места. Длился он до трёх-четырёх месяцев, и был связан с огромным фризическим напряжением.

Основнылм средствол передвижения у коли охотников были калуснье льюи и ручные нартьь, которье тащили с полощью реленной упряжи. Грузоподъёлность охотничьих нарт достигала 10-12 пудов, но передвижение груза более 8-9 пудов даже с полощью собак было тяжёлой работой. При длительньх подъёлах охотникал приходилось оставлять часть груза и впрягаться в нарты по двое, за оставшился снаряжениел возвращались на следующий день. Поэтолу в дальние и особенно длительнье артельнье походь из продуктов брали только салое необходилое, ограничивая рацион до предела. В среднел на охотника и его лайку при пролысле длительностью более двух месяцев бралось около 30 фбунтов продуктов на неделю, на более короткий срок норла бьла несколько больше. Кроле продуктов питания, каждый из участников охотничьей артели брал с собой запас пороха (до 3 фбун.) и свиниа (3-4 фбунта), если на вооружении охотника было пистонное ружьё - то коробку пистонов на $100 \mathrm{~mm}$. (Конаков 1994: 126)

Важными качествами охотника у коми, в основном добывавших зверя пассивными ловушками и подолгу выслеживавших по следу, считались терпение и наблюдательность. Изменившаяся погода могла скрыть следы зверя, загнав его в лежбище, надолго 
Тяготы пути нашли широкое отражение в народной поэзии. Так, в свадебной песне парень-охотник поёт:

Кокӧй менал чукьльтчис Кузь туй дженьдӧдӧмьıсь... Гӧрбӧй менам быдмис Кузь норт кыскалӧмысь... Ньрӧй менал чукьльтчис Ур нырисалӧмыссь...

Синлиӧйленал тальєшлис Коз йьлльссьур кьийӧӧльıсь...
У меня ноги искривились От сокращения долгих путей... У меня горб вырос

От перетаскивания длинных нарт...

У меня нос искривился

От вынюхивания белок...

У меня глаза окосели

От высматривания белок с вершин елей...

(Микушев 1969: 39-41)

запереть охотника в избушке или отрезать доступ к провизии. Отсюда необходимость вырабатывать в себе умение довольствоваться малым. В частности, охотник коми, в случае удачи способный съесть несколько килограммов мяса, мог сутками жить, питаясь только сушёными тушками белок и куниц (кyриньга), которые обычно шли в пищу собакам, и руководствуясь поговоркой Талун олал, а аски, колӧкӧ ӧшинь улӧ йӧра локтас 'Сегодня живы, а завтра, может, на двор лось придёт'.

Сьӧдбӧж куриньганас тшынсені кутшелке виселись. Сіес пон оз сёй, зэл дука, понъясідлі оз ий сетні. Ур яй эз сёйліні, понлі сетлісні векджик. Мукед дыр-йиис эське сёйлэні же да, тшыг кадэ либе код велалэла. Кодсюрэ шувені: лунтыр кежлэ пе, ур вит питшегад сюян да, тырле, лунтыр пӧт. Уртэ ачил на сёйлі. Пӧт эське вӧлі да, сідз-интерес. Кунича ку-
Сушёным горностаем окуривали от каких-то болезней. Собака его не ест, очень вонючий, собакам и не дают. Беличье мясо не ели, собаке давали чаще. Хотя иногда едят, в голодное время или кто привык. Некоторые говорят: на целый день, мол, белок пять за пазуху положишь, и хватает, целый день сыт. Белку и сам ел. Сытый был вообще-то, но так, из интереса. Сушёную куницу - собакам, внук сам, 
риньга-поньяслі, внук тай ачис сёе вӧлі. Гежед пон куничатэ пӧжалтэгид сёе. ${ }^{2}$ бывало, ел. Редкая собака куницу без запекания съест.

Естественно, долгие кампании были сопряжены с множеством опасностей, связанных как с природными стихиями, так и с естественным противником охотника - крупным зверем, который в любой момент мог превратиться из добычи в добытчика, о чём говорят поговорки типа Петан ош вылӧ, лӧсьӧд небыд вольпась, петан йӧра вылӧ, лӧсьӧд гу да горт 'Выходишь на медведя, готовь мягкую постель, выходишь на лося, готовь гроб с могилой'; Оштӧ он аддзы, ошкыд тэнӧ аддзас 'Медведя не увидишь, медведь тебя сам увидит'; Ошкыдлӧн черыс-пуртыс век сьӧрас 'У медведя топор-нож всегда при себе'. По бытующему у коми мифологическому сюжету, медведь попросил у Бога-Ена (вариант: Николы Угодника) себе большой палец:

Микела ий шувас: "Сета ке тәд пев, лен ковлас мортлісетні борд, а понлі ньӧвуж». Ся ошкид кььвтэ косэдас, но корас куйил лун вӧрин ьджидавні. Ен сетас сілі ьджидавні вӧрин ий мортлі шувас: "Селен лун бӧрсянь Пӧкрэведз сета ошлі куйил лун вӧля, кор, тэнід ог висьтоо. Сія луньясас ас вилад надея кут, ме нинэлен ог верли отсооні». Ся ий вӧля ошлі. Куйил лунсэ видлі тӧдлооні!
Никола и сказал: «Если тебе дам большой палец, мне придётся дать человеку крылья, а собаке лук со стрелами». Тогда медведь слово обратно взял, но попросил три дня полной власти в лесу. Ен дал ему полную власть над лесом и сказал человеку: «После Семёнова дня до Покрова даю медведю три дня свободы, а какие дни, тебе не скажу. В это время на себя надейся, я ничем не смогу помочь». Вот и воля медведю. Попробуй три дня эти угадать!

Для того чтобы не обидеть зверя, в котором коми видели достойного противника, и во избежание утраты удачи, что могло привести к голодной смерти, травмам и гибели, обращение с добычей обставлялось запретами и предписаниями. 
Поскольку некоторым животным (в частности, медведю, волку, белке) приписывалось понимание человеческой речи, считалось крайне нежелательным упоминать их в разговоре или призывать заранее. Некоторые эвфемистические термины закрепились в современном коми языке: рысь - вӧркань букв. 'лесной кот', горностай - сьӧдбӧж букв. 'чёрный хвост', лось - йӧра букв. 'мощный', лола букв. 'имеющий душу', ср. коми-пермяцкое вӧрлӧс букв. 'лесная корова' и т. д. Нельзя было хвастать добычей, а тем более называть её количество. Только во время разделки или опаливании произносили:

Пач кьлмӧс самында, порог ув ёг миьнда шед;

Чищки-порищки аски дасӧн;

Чищки-порищки айтӧлиалтӧ чукӧст, рӧдтӧ-вужтӧ чипӧст айлӧн пиштшаль водзӧ, айлӧн чӧстуй вылӧ, турыштчы да порыцтчиь ьджыд кодз меж ьљжжда! (ПМА)
Сколько сажи в очелье печи, сколько сора у порога, столько ловись;

Пались-опаливайся, завтра десяток;

Пались-опаливайся, отцамать призови, род-корень высвисти перед отцовское ружьё, на отцовские путики, обернись и свернись с кастрированного барана величиной!

Нельзя было жалеть зверя или принижать его достоинства. Так, про одного охотника рассказывали, что он какое-то время вынужден был белковать с «пистонкой» со сломанным курком:

Тайӧ пистонкаясыс Епим Ёгорыслӧн на (Завод И. Ф. Петров, 1911 г.). Епил Ёгорьслӧн пистонкасьььс курокыс вӧлӧл чегӧма. Ся ки пӧвнас босьтӧ вӧлӧм, летитчӧ
Эти пистонки ещё у Егора Ефимовича (Завод И. Ф. Петров, 1911 г.). У Егора Ефимовича курок пистонки сломался. И одной рукой брал, прицеливался, и по пистону кончиком ножа бил. И главное ведь 
да пистонас пурт йылӧн вартӧ. И главнӧйыс вӧд синлиас инлӥ вӧлӧл уріслі. ${ }^{4}$ в глаз попадал, оказывается, белке.

Однако стоило ему один раз поставить себя выше зверя, как леший его наказал.

Кьянтортэ либе начкантортэ некор жалитні оз ков. Оз кув. Епил Ёгорпӧле корке ур кыйиген жалитлэла. А зэв вед бура льйсе вӧлэл. Урсэ аддзема да: дзик пе конер койд. "Ок пе, конерэй, конерэй, лья да, вед ий усян». Ся став припассэ кутшелке кулем уридлі льйлэла, урид пе весиг эз вӧрзив. Матектэма да керкаас мунэла. Оз позь ошйисьні водзвив ни жалитні, кыйні ке нін петэлид. Ся шуласні: кваст да горш мортлі пе кулем урид петкедче. Бытте сэтшел же лӧз ур, тольке кучиктэл. ${ }^{5}$
Кого ловишь или режешь, никогда жалеть не надо. Не помрёт. Егор Ефимович, мой дед, когда-то на белковании пожалел. А хорошо ведь стрелял. Белку увидел: и совсем уж, мол, жалкая. «Ох, мол, бедолага, бедолага, выстрелю ведь, и упадёшь». После этого все припасы в драную белку расстрелял, белка, мол, даже не шелохнулась. Выматерился, к избушке пошёл. Нельзя хвастать заранее ни жалеть, если уж ловить вышел. Ещё говорят: хвастливому и жадному ободранная белка показывается. Будто такая же синяя белка, только без шкуры.

Обязательно полагалось добивать зверя: оставлять подранка считалось не только негуманным по отношению к нему, но и опасным для охотника. После поимки ценного зверя, ему оказывалось особое почтение. Коми охотники в этом случае устраивали ужин из лучших продуктов. Снятая шкура вывешивалась на видном месте, тушка соболя или куницы закапывалась в ямке, выкопанной на кострище. В беседе, сопровождавшей ужин, о звере говорили исключительно доброжелательно (Конаков 1994: 146-147). 


\section{«Совпадение по крови»}

Дикому зверю, наделённому рефрлексами, природной чуткостью, острыми зрением и слухом, охотник должен был противопоставить свой интеллект, напряжённое внимание и человеческие умения, а также природные качества зырянской лайки, незаменимой помощницы, защитницы от зверя, лесных духов, обладающей универсальными способностями, способной учуять и удержать крупного зверя, облаять белку, выследить соболя или куницу. Во время индивидуальной охоты собака была единственным товарищем и «собеседником» охотника, поэтому её наделяли и магическими способностями. Так, считалось, что между ног собаки можно увидеть лесного духа, а «четырёхглазые» собаки (тёмные со светлыми бровями) сами способны видеть духов и отгонять их. Собака настолько была связана с хозяином, что, по поверьям, три поколения убийцы собственной собаки не могли завести новую, а убитое животное встречало душу хозяина после его смерти при переходе через огненную реку по жёрдочке и не пускало на тот свет.

В условиях длительного пребывания вдали от населённых мест, когда невозможно было получить помощь со стороны в случае болезни, травмы, жизнь, а также добыча промысловика во многом зависела от него самого и от тех, кто находился рядом. Тем важнее был правильный выбор сотоварищей для охоты, с которыми предстояло провести длительное время. В этом плане весьма интересными являются представления коми о «сходстве по крови» (вир лӧсялӧл), то есть психологической совместимости. Под сходством или близостью по крови подразумевалась не родственная близость, а близость духовная, метафизическая способность определённых людей понимать друг друга и помогать не только действием, но и самим своим присутствием: Вирид ке лӧсялэ, став уджис артле, вирид ке оз лӧсяв, кӧть кутшел буресь да пралеесь, нинэл оз артли 'Если кровь сходится, всякая работа получается, если кровь не сходится, какие бы ни были добрые и хорошие, ничего не получится'. Сотрудничество людей, несходных по крови, заранее обречено на неудачу. В силу существования данного представления, товарищи в охотничьи артели подбирались не только 
по профессиональным качествам и надёжности, но и по психологической совместимости. В случае неправильного выбора сотоварищей неизменно возникали споры (хотя добыча в конце сезона делилась равномерно) и ссоры, вызванные не только ревнивой завистью к чужой удаче и жадностью, но и принципиальным «несходством по крови», которые могли закончиться как физической расправой над бывшим сотоварищем, так и порчей собаки или оружия. При повторных неудачах дело доходило до обвинений даже самых близких родственников и друзей. Так, один верхневычегодский охотник подозревал отца-старика в порче остроги и ружья:

Васе-воке кулэлсянь сілэн ружьеис быд во на йӧра лыйиген осечкаавліс [...] Мылл-а сідз? Меся, бате ружьесэ керис ли, льий ли? Вась кулэлсянь эське эг нін сетлі кутчисьнісэ. А код ся тӧдас? Бать менэ ий чили кыбиген волдзавліс. Чери пью улӧ зутшки. Ся лӧдэс казялі. Воддзаислэн моз сӧлин бӧжис легедче колода саяс. Тойишті, пьюал лэпті, а бать абу казявлэла: "Мый нэ калалан?" Да, танэ тай, шува, "колnи" шедіс. "Да-а, тая, шуве нылма "колпи». Тэнід чериис ачис ке азьласад пьсасе-я?» Ся койлед вӧлі, да муніс. Сісянь эз нін сюрлі чили быттикині. ${ }^{6}$
Со смерти брата-Василия его ружьё каждый год ещё при стрельбе по лосю давало осечку. [...] Почему так? Думаю, отец что ли ружьё испортил? Со смерти Васи, правда, не давал прикоснуться. А кто знает? Отец меня и при лучении сёмги как-то сглазил. Рыбину я забил под лодкой. Потом вторую заметил. Как и у предыдущей только хвост шевелится за колодой. Ткнул, поднял в лодку, а отец сперва и не заметил: «Что ты там шумишь?» «Да вот, говорю, "хариус" попался». "Да-а, это, говорит, подходящий "хариус". Тебе рыба сама что ли на острогу цепляется?» Потом третья была, и ушла. С того времени уже не удавалось сёмгу залучить.

Судя по фольклорным текстам, споры между охотниками нередко перерастали в колдовские «дуэли»: 
Кьк тӧдісь кьйсиген вензясні. Ся ӧтикис мӧдіслісь кӧм волессэ бергедас. Мӧдіс асівнас кьйсині петас, и керкасянис вешйині оз верли: вит-э-квайтісь кьтшоотас лунтырнас, век керкаланис локтэ. - Вай пе бергед, мыьй керин. ${ }^{7}$
Двое знающих на охоте поспорили. Потом один взял и у другого стельки развернул (носком назад - прим. авт.). Тот утром на охоту пошёл, и никак не может от дома отойти: пять-шесть кругов за день сделал, всё время к избушке возвращается. - Давай, мол, переделай, то, что натворил.

Избегать ссор и прямых столкновений помогали особые механизмы социальной регуляции и коммуникативные правила. Несмотря на традиционно культивируемое уважение к старшим, основным принципом взаимоотношений в коллективе было абсолютное равенство членов, начиная с того, что, невзирая на разницу в возрасте и в общинном (мирском) статусе, друг к другу обращались на «ты» и по имени, и кончая тем, что имущество и орудия промысла (кроме ружья, ножа и собаки) были в общем пользовании. Проблемы решали, прислушиваясь к каждому предложению, хотя при принятии решения всегда учитывались опыт и мудрость собеседников, способных в трудных случаях апеллировать к традиции или прецедентам. В общении, разумеется, не исключались юмор, ирония и сарказм, как средства мягкого убеждения, особенно в отношении младших по возрасту, но абсолютно недопустимым считалось игнорировать чужое мнение, даже если оно не совпадало с личным. Особенно же остерегались резких высказываний в адрес оппонента и избегали негативных характеристик. При совместной охоте товарищи вели себя по отношению друг к другу максимально корректно, что в некоторых случаях приводило даже к курьёзным случаям. Так, на верхней Вычегде рассказывают о двух охотниках, которые два месяца были на лосиной охоте. Накануне возвращения домой они поужинали, и один отошёл от стола. Второй спросил: «Ну что, не будешь больше? Тогда я посолю ещё и доем». «А что, ты тоже солёным ешь?!» - удивился первый. - «Тогда и я поем тоже». Оказалось, что оба едят солёное, но, поскольку, в начале охоты еду случайно недосолили, то каждый из них решил, что 
напарник предпочитает недосол, поэтому из корректности не высказывался о своих вкусовых пристрастиях.

Жизнь в артели приучала к честности по отношению к товарищам, утайка своей добычи от них считалась одним из непростительных грехов, за который из артели изгоняли так же, как и за трусость.

Поощрялась личная храбрость. На верхней Вычегде до сих пор вспоминают охотника, который в начале века добыл более сорока медведей:

Ме сілісь ювала: “Кьљз тэ ошбяссэ кьян?" А сія шуве: "Дасідз ий кьюя. Лэдза, миьй верла, латэ, пищалидтэ менали лёкиник. Вот кыљз матісччас некьлмин воськоо ьцлна, ся й льц». ${ }^{8}$

Я у него спрашиваю: «Как ты медведей добываешь?» А он говорит: «Да так и добываю. Подпускаю, как можно ближе, ружьё-то у меня плохонькое. Вот как подходит на несколько шагов, так и стреляю».

И всё же выше личной храбрости считалась смелость, проявленная ради спасения товарища: человека, оставившего товарища один на один с медведем и своевременно не перезарядившего ружьё, больше не брала никакая артель.

Серьёзными нарушениями охотничьей этики считались занятие чужих промысловых угодий, охота на чужих угодьях, обгон другой артели, пересекание чужой лыжни (поскольку при загонной охоте лыжнёй очерчивали местонахождение зверя) и присвоение чужой добычи. В том случае, если охотник убивал зверя, которого загонял другой, он отдавал добычу преследователю зверя, а тот возвращал израсходованные боеприпасы. В том случае, если охотник не отдавал добычу сразу и был вынужден признаться под давлением, он должен был ставить спиртное, что и считалось актом примирения, хотя в этом случае утаившего в дальнейшем не брали в промысловые артели. Споры об угодьях обычно решались мирным путём, при этом преимущественное право на пользование давало «наследование» территории:

Отеи улер, так я большой круг оставил, года четьре не ходил по толу кругу. Ближнего круга хватало. А потол, 
дулаю, надо и тали восстановить слопцы, дичи лало стало. Начал тал слопиы делать, а слотрю: кто-то рядол уже поставил. Три или четыре слопиа стоят. Как-то потол обхожу, а рядом с моим слопиом на дереве бересты кусок прибит. Нацарапано: "Кто на мои путики так нахально зашёл? Поговорить надо». И подписался один мужик из дер. Лыльва, вишерский. Пошёл к нелу, бутылку взял, он чуть драться не лезет: "Ть зачем на мои угодья влез, места что ли мало?!" А я говорю: "Что за ультилатул такой? У меня отеи ещёз зесь охотился, могу его зарубки старые показаты». Привёл. Показал. Тал даже отиовский пас [родовой знак - прим. авт.] под слолой сохранился, отковыряли. "Ладно, -говорит, - извини. Слотрю: никто не охотится, а дичи лного здесь, вот я и расширился. Отиа твоего знавал, но не знал, что он досюда доходил». Так и договорились. Он передвинул свои слопцы нелного, и я чуть-чуть. ${ }^{9}$

Начиная с 1940-х годов, когда в Коми крае появилось много ссыльных и наёмных людей, незнакомых с местными традициями и естественным правом на угодья, стали возникать разногласия между коми и пришлым населением, которые разрешались по-разному, иногда и анекдотически:

Кодке менам угӧддеин кузь лунтыр калге пищались. Код нэ сэтшелис, мать mypypy!? Но, думайта, сё ровно орділедіс керкалань узьнісэ петас. Рьчтланис локтэ кодке. Ме кыкнан стволсэ пуляэн зарадиті, пукала керкаин, виччися. Дулайта, стразу лыйні али куш поозедні. Пьре ӧти сыльнэй Вӧрчер лагпосёлокись. Ме шува: «Мый нэ керсян!? Мыля-а менали угодде вылін шковган? Ме
Кто-то целый день у меня на угодьях из ружья бухает.

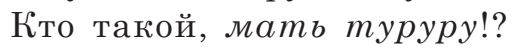
Ну, думаю, всё равно по тропе ночевать к избушке выйдет. Под вечер идёт кто-то. Я оба ствола пулей зарядил, сижу в избушке, жду. Думаю, сразу стрелять или напугать только. Заходит один ссыльный из лагерного посёлка Вӧрчер. Я говорю: «Ты что это делаешь!? Зачем на моих угодьях стреляешь? Я сам боюсь чихнуть, чтобы 
ачим несйині пола, мед пӧткасэ не поозедні-я!» А сія шуве: "Ме вед эг тӧд, мицй тәяд угӧддейис. Танэ пе, верла джьн сьӧласэ кольні». Ме шува: "Кутшел джьн!? Тая сьӧлаис ставис менал, сёр ли, водз ли, чӧскал-лэчкал эське шедіснін. А сія поозис (ленал ствол чургедэла): "Ладнэ, - шуве, - босьт ставсэн. (Ньлиен оз бӧрддзи). Гузьгис нопсис, а сэн кеняяс, ноп mьıрис. "Но, думайта, бур нін, тая рӧзбойникъясісь мездіс да (ная вед пӧтка кольктэ ёна гусёолэні). Ладнэ, шува, первой скон прӧстита, но мӧдісь мед менал угодде вылін абу вӧлі льйсела. "Ог! Ог!" шуве. Ебенанемать! ружье небема да, чайтэ ий кыйсись ловис. Но бӧрас куйим доз сьпирт меніл пуктівліс же, некод, бураке, абу висьталэла, мьий сьӧлаид лӧз яя кенясид торбяліштэ неуна. ${ }^{10}$ дичь не распугать!» А он отвечает: «Я ведь не знал, что это твои угодья. Вот, могу половину рябчиков оставить». Я говорю: «Какая половина!? Эти рябчики все мои, рано или поздно в слопцы да силки бы попались». А он испугался (ято ствол наставил): «Ладно, говорит, - бери всё». (Чуть не плачет). Вываливает из мешка, а там - ронжи, полный мешок. Ну, думаю, это хорошо, что от разбойников избавил (они же у боровых птиц яйца воруют). Ладно, говорю, на первый раз уж прощаю, но больше на моих угодьях не стреляй. «Не буду! Не буду!» говорит. Ебенанелать! ружьё купил, думает - уже охотник. Но три бутылки спирта он потом мне поставил, никто, наверно, не сказал, что рябчик немного от синемясой ронжи отличается.

Несмотря на данные о том, что артель нередко состояла из охотников разных районов и пополнялась по пути (в частности, имеются данные о том, что верхнепечорские и верхневычегодские артели брали опытных охотников из деревень по р. Илыч), до сих пор существуют тексты о стычках, время от времени переходивших в подобие военных столкновений между коми и хантами, удорскими коми и пинежскими русскими, печорцами и вычегодцами (ЭУМ 1999: 404; Конаков 1994: 170). 
Войдортэ тай ёна миян воюйтлӧлаэсь уграидкед, ӧстякгясідкед, вӧралан угӧддеяс веснаид, Урал вылас ий, Урал саяс ий. Корке войнаэдзис на, висьтавлісні. Сэк вӧралан бригадаяснад ёна ветлісні да. Бригадаясіс, биясясні да, коді водзжык вой кежлад сувтас да биясяс, наес и начкені вӧлэл. Ӧстякид ке биясяс водзджик, миян наес виясні. Миянлісь ке налі удайтчас суні, гусен сибедчині бипур дорад, миянлісь кьрлаласні. Тая двадиатойтридиатой годъясас вӧлэла. Да й сёренджик на. Дашкен ий, пушнинанад эз торъя озір Сибирыд вӧ, миян же тоже ставис вӧлі, ӧні тай этша колис-а. Но сэсь волӧлась озыр прӧлисэн. Либен вобшӧ абу волэлась. Ӧти мужиклэн тай угӧдде вӧлэм Тюменскей областискед орччен. Этая Сибираковскей трактсянис водзе на. Ся ӧстяк ая-пиа доре веськалас. Вийні сіес кӧсъясні, кор мунні кутас. Гӧсьт койд да, бытте абу мича керка шӧрад вийнітэ-я. Ся шапкасэ коляс, петавла пе ыллаэ. Ся пышыяс. А войнас вӧлэла, да бушкола, да туйсэ тыртэла. Воштэлаэсь сіес. Эся пе ме ӧтнал некор ог мун сэтчи. A кодке тай пьр ветлэла. ${ }^{11}$
Раньше наши много воевали с уграми, с остяками, за охотничьи угодья, и на Урале, и за Уралом. Ещё до войны, рассказывали. Тогда охотничьими бригадами постоянно ходили. Бригады, когда костёр разожгут, кто раньше на ночлег остановится и огонь разожжёт, тех и резали. Если остяки раньше костёр разведут, наши их убивают. Если наших им удастся застигнуть врасплох, тайком подобраться к костру, наших перережут. Это в двадцатые-тридцатые годы было. Да и позже ещё. Может и пушниной не особо богата была Сибирь, у нас же тоже всё было, теперь мало что осталось. Но оттуда возвращались с богатой добычей. Или вообще не возвращались. У одного мужика угодья были на границе с Тюменской областью. От этого Сибиряковского тракта ещё далее. И он попал к остякам, отцу с сыном. Убить его хотели, когда уходить будет. Вроде, как гость, и некрасиво в доме убивать. И шапку в доме оставил, схожу, мол, на улицу. И убежал. А ночью было, и метельно, и следы замело. Потеряли его. Я, мол, один туда больше не пойду никогда. А кто-то ведь и постоянно ходил. 
Разумеется, рассказы о настоящих военных столкновениях относятся больше к глубокой древности и к области фольклора, тем не менее, в какой-то мере они подчёркивают непростоту взаимоотношений между артелями этнолокальных групп и сложности промысловой жизни. О стычках из-за права на промысел в Приуралье между верхнепечорскими и верхневычегодскими коми, правда, уже без смертельного исхода, происходивших в тех же 1930-х гг., вспоминают ещё дети непосредственных участников:

Здесь в старину осеннюю охоту начинали в октябре. На Печору ходили. Печорские их ненавидели, пушнину отбирали. Как-то наши в лес ушли. А хозяйство ведь такое: шалаш сделают, овчина, эшкын [овчинное одеяло с карманом для ног - прим. авт.], да и всё. Один остался чтото готовить да сторожить. Печорские пришли, его одного-то избили, вчерашние шкуры отобрали. (А остальное наши спрятать успели). Охотники вернулись: всё разграблено, раскидано, товарищ избитый. А пожегодские и полоздинские [артели из верхневычегодских сёл Пожег, Помоздино, т. е. земляки - прим. авт.] рядол где-то охотились. Их позвали, и человек сель-восель к печорсколу стану отправились. У печорских тоже один сторож только. Сторожа избили, ружья перелолали, шалаши сожгли, пушнину отобрали. Обратно вернулись. ${ }^{12}$

Следующий случай имел местоужев 1980-егг. на верхней Вычегде:

Миян угӧдде помас дзик керкасӧ пуктӧла: ме пе вед кыйні ог кут, чери кыцині кута куш. Паськид йир кыр йылас, алиян салей сэтче ьљжид кьттис петэ. Но, пока керкасэ тиупис, Bace кыкись струбсэ быгледліс, йирас шьблаліс. Кӧзяиніс пинясьні воліс, и сё ровно керкасэ лэптіс. Эся Васе керкасэ сотіс, сэн пе и кулэлгяс, и гылигаяс, и став оолесіс нін вӧлі. Да вед сія
На границе наших угодий он избушку поставил: я ведь, мол, охотиться не буду, только рыбу буду ловить. На берегу Паськид йир (Широкий омут), а у нас как раз туда большой круг выходит. Ну, пока избушку рубил, Вася [брат информатора - прим. авт.] дважды сруб раскатывал, в омут бросал. Хозяин ругаться приходил, и всё равно поставил избушку. Тогда Вася избушку сжёг, там говорит, у него и сети, и морды, 
бара на керкатэ тиупис да кутшелке скӧредулса мужиклі вузаліс. Вась скӧредулсаискед сёрнитліс, а сія шуве: ме пе эг тӧд, мыцй сэн тіян угӧддеяс. Ӧні ся керкаис эндэл сулалэ. ${ }^{13}$ и всё имущество уже было. Так этот ведь опять избушку поставил и какому-то скородумскому мужику продал. Вася со скородумским поговорил, а тот и говорит: я, мол, не знал, что там ваши угодья. Сейчас избушка бесхозная стоит.

За серьезные проступки наказывали «отложенной» смертью. По литературе и полевым данным известно несколько способов наказаний, которые могли закончиться смертельным исходом, но при этом наказывающие формально не становились убийцами, потому что наказанному всегда давали шанс выжить. В одном случае, вору продевали в рукава жердину и привязывали к раскинутым рукам (потшкӧн лэдзӧл 'отпускание с жердью'). В таком виде человек не только должен был дойти до деревни, но и найти человека, который бы освободил его, не испугавшись разделить с ним вину, на что решался далеко не каждый. В другом случае, волосы наказуемого прищемляли в стволе дерева с помощью клиньев (сарӧ пуктӧл 'воцарение'). В третьем случае, виновного поджигали в избушке, подперев двери. На верхней Вычегде рассказывают о некоем М. М., которого за воровство несколько раз пытались убить, один раз забили вёслами и кинули в воду, в другой раз подожгли вместе с избушкой. В первом случае он выплыл и посуху быстрей обидчиков дошёл до дома, во втором случае подкопался под стенкой горящей избушки, после чего местные жители переделали известную загадку про лёд: Биьцн оз сотчьь, ваьıн оз вӧй-M.M. 'В огне не горит, в воде не тонет. Отгадка: М.M.’. В 1930-х годах также один из верхневычегодских охотников наказал охотника-соседа за воровство рыбы из морды тем, что, порубив штаны вора, заставил его голым в самое комариное время отнести к своей избушке (за несколько километров) и почистить пойманную рыбу, после чего отпустил. Иногда вора поили и сулемой, которую использовали при ловле лис и волков, или оставляли на столе отравленный рыбник. Весьма распространёнными в коми несказочном фрольклоре являются сюжеты о наказании охотника, совершившего тяжкий проступок, с помощью магии (вплоть до смертельного исхода). 


\section{«Кровь шалит...»}

Одной из проблем психологического характера была необходимость справляться с проявлениями бессознательного и «сверхсознания», которые в экстремальных ситуациях доминируют над обыденным подсознанием мужчин (Серов 2002: 30).

Одиночное или коммуникативно-ограниченное пребывание в опасной стихии, при наличии сильной мистической традиции в культуре коми и на фоне постоянного психологического напряжения и ожидания, нередко вызывало у охотника депрессию, страхи или галлюцинации, объясняемые тем, что у человека вирыс ворсӧ 'кровь играет / шалит' или вирыс повзвӧдлӧ 'кровь пугает'. Отсюда - многочисленные былички о встречах охотника с лесными духами, среди которых значительное место занимают тексты о сожительстве охотника с лесной женщиной. Жизнь в сугубо мужском обществе или в одиночку естественно накладывала определённый отпечаток на психическое состояние. Если с обычными бытовыми женскими обязанностями удавалось справляться, то эмоциональные привязанности к домашним, любимой девушке, женщине, особенно у молодых охотников, видимо, были достаточно сильными и вызывали иногда фантазии, выходящие за пределы нормы. Василий П. Налимов в начале $\mathrm{XX}$ в. упоминал о распространённых среди охотников рассказах про «лесных жителей» вӧр ольсь, женщины которых отличаются прозрачностью или матовой бледностью, поют «сладкими и нежными голосами» и «охотно сожительствуют с мужчинами». Впрочем, по другим его материалам, лесные женщины бронзовотелы, некрасивы лицом, прыгают с дерева на дерево и кричат пронзительными голосами (Налимов 1903: 77-78). В быличках к охотнику, нарушившему запрет на упоминание о жене или подруге, в её образе приходит лесная женщина, с которой он живёт весь охотничий сезон. Лишь в конце сезона или на следующий год раскрывается её нечеловеческая сущность: охотник с «женой» подплывают к деревне, и при виде церкви женщина бросается в воду. Или через год некая обнажённая женщина с ребёнком просится в лодку к охотнику, поднимающемуся на угодья, а после отказа охотника разрывает ребёнка пополам и исчезает в лесу или в воде (Му пуксьӧм 2005: 379-388). 
Видимо, подобные сюжеты, множество раз «прокрученные» в обострённом сознании и в ночных сновидениях, приводили некоторых мужчин с особо неустойчивой психикой к патологическим формам ревности.

Чтобы не сосредотачиваться на нежелательных переживаниях, в охотничьей среде существовали запреты на произнесение и на упоминание во время промысла не только нечистой силы или лесных духов, но и названий вещей, явлений, людей, которые так или иначе входят в женское, деревенское семантическое поле и под видом которых могли появиться духи-оборотни. Так, женщину эвфемистически следовало называть тшӧтшыд ‘без выступов', чышъяна 'в платке', священника - кузь юрси 'длинноволосый', сьӧд паськӧла 'в чёрной одежде', кошку - нӧк гусяльсь 'сметану крадущий' и т. д. Подобные регламентации связаны с представлениями о мужской и женской сферах культуры, в некоторых сегментах исключающих взаимопроникновение:

Туйӧ петігӧн баба ли поп кӧ воча лоё - оз везит;

Поп ли баба кӧ кыян кипельтӧ вожмаласнь сіе тшынны колӧ;

Вась Ӧле вӧлі, прӧльцляйтнітэ петіген ке кӧлтэл морт ли, баба ли, поп-дяк ливойчча лове, сьӧліштэ да бӧр косэ. ${ }^{14}$
Если перед дорогой женщина или поп навстречу попадутся - не повезёт;

Если поп или женщина перешагнёт через снасть - её нужно окуривать;

Алексей Васильевич было, если при выходе на промысел босой человек или женщина, или священник навстречу попадётся, сплёвывал и возвращался.

В сказках о «беременном» псаломщике, о богатыре, рождающемся от интимной связи попа и быка/ медведя/ лешего (ФНК 1938; КМС 1963; КМ 1991), в приметах и фрразеологических оборотах, женщины и священники объединяются в едином семантическом поле «деревенского пространства».

Дифференциация мужских и женских представлений прослеживается и в отношении к священникам ${ }^{15}$, и в разной оценке 
мифологических образов Олӧля и Вӧрса. Олӧль женщинами отождествлялся с библейским Сатаной, мужчины же преимущественно видели в нём лишь невезучего и проказливого брата небесного божества-Ена. К лесному духу Вӧрса отношение мужчин было равное, почти панибратское: считалось, что с ним можно (не без выгоды) подружиться или приручить его. Женщины же, с одной стороны, воспринимали его хозяином природной сферы в целом, включая власть над окультуренными угодьями, домашними животными и здоровьем людей, а с другой стороны, отождествляли с Сатаной. Исходя из аксиоматического высказывания: «зырянин - православный, пока живёт дома, в своей деревне, но как только заходит в лес, становится язычником» (Налимов 1903: 84), в целом, можно говорить о земледельческой и народно-православной ориентации женской сферы и о преимущественно промысловом и натуррелигиозном характере мужской.

Именно это определяло «правильные» культурно-поведенческие стратегии и женщин, и мужчин, которые, впрочем, могли меняться, в зависимости от изменяющейся обстановки и ситуаций. В частности, в отсутствие мужчин женщины выполняли многие их обязанности, а мужчина в охотничьем быту был вынужден заниматься сугубо женскими делами (шитьём, готовкой, стиркой), то есть экстремальная ситуация вносила поправки в представления о «норме».

\section{«Пробивающий лыжню...»}

Все сложности промысловой жизни с её постоянным физическим и психологическим напряжением, помогал преодолевать сказитель или музыкант, которого часто брали с собой промысловики. Этот артельщик-сказитель не только вёл хозяйство (заготовка дров, готовка пищи), но и рассказывал вечерами истории и сказки до тех пор, пока не уснёт последний охотник. Сказитель обычно не принимал прямого участия в охоте, находясь практически неотлучно в охотничьем лагере, тем не менее, в конце сезона он получал равную со всеми часть добычи. Иногда роль сказителя 
отводилась главе артели, который, по определению, должен был обладать знанием традиций и фольклора.

С возрастом промысловик привыкал к таёжной жизни настолько, что многие пожилые охотники, для которых такая жизнь стала нормой, предпочитали появляться в деревне только с целью продажи добычи. Именно таких, удачливых и опытных промысловиков начинали приглашать в артели в качестве проводника или руководителя - юр 'голова, глава' или юрка, юревей 'главенствующий, главный', айка 'старик, хозяин'. В их задачи входило не только определение промысловой стратегии, но и разрешение тактических вопросов: бытовое обустройство, лечение членов артели и собак, выбор промысловых ареалов и предпочтительной добычи, разрешение конфликтов внутри артели и налаживание отношений с чужими артелями. В пути глава шёл налегке, поскольку пробивал лыжню. Когда артель останавливалась на месте будущего лагеря, он садился на пень специально срубленного для него дерева и давал распоряжения. Он же указывал направление и участки, на которых должен охотиться тот или иной член артели, назначал дежурство по хозяйству, определял длительность охоты на том или ином участке пути, тип наиболее предпочтительной в данный момент и на данном месте добычи. Он же определял время перемещения на другое место, когда зверь поблизости был почти весь добыт. Приказы его исполнялись беспрекословно, хотя во время обсуждения любых вопросов каждый член артели имел право высказывать своё мнение. В конце сезона глава делил добычу: как правило, шкурки мелких зверей раздавал по счёту, а за неделимую на всех добычу (шкуры медведей, лосей, редких зверей и т. д.) отдавал деньги, вырученные за их продажу.

Особо значительна была роль главы в экстремальных ситуациях, когда ради сохранения артели, а то и человеческих жизней, порой приходилось искать нестандартные решения, и от мудрости и житейского опыта старшего зависела жизнь каждого. Показательна быличка, записанная у охотников на верхней Вычегде: 
Сибире мунасні артелен. туребкыптас, чолсис петнісэ оз верлині. Син ни пель. Вежон сідз дай, мӧд дай. Век туреб. Кьийні нинэл оз верлині, сёян бьре. Тшыгъёоні кутасні. "Вай пе скондясял да ӧтикес сёял, не же пе ставлі тшыцлі кууні». Сконбясясні, начкасні ӧтикес. Юрніс шуве: "Вай ме первой видла, колэке оз шогми». Някляліштас яйтэ да сьӧліштас. Яй шыљбтасні. А старик чӧв олэ, нинэл оз шу. Гортас вовасні, да вӧлисти шувас: "Аттэ, лорт яйид чӧскид вӧлэла. Висьталі ке, ставніл ӧта-лӧдэс сёйил». А кыдзке ештше бушколід лӧнела, да вель на уна кыелаась, и тшыглі абу кулэлаась. ${ }^{16}$
В Сибирь пошли артелью. Буря поднялась, из шалаша выйти не могут. Ни зги не видно. Неделю так, и другую. Всё буря. Поймать ничего не могут, и еда кончилась. Голодать стали. "Давайте, мол, жребий кинем и одного съедим, не всем же с голоду помирать». Жребий бросили, зарезали одного. Старший говорит: «Давайте я сначала попробую, может не годится». Пожевал мясо и выплюнул. Мясо выбросили. А старик молчит, ничего не говорит. Домой вернулись, и только тогда сказал: «Человеческое мясо такое вкусное, оказывается. Если бы сказал, все бы друг друга съели». А как-то ещё пурга прекратилась, и довольно много ещё поймали, и с голоду не померли.

Данный текст почти слово в слово повторяет текст, записанный Давидом Фокош-Фуксом в сороковые годы прошлого столетия:

...Наяас тӧльсь-лӥд ветласні. И ная гортаніс бергедчасні. А неуна суутасні да ий ӧпек кыйсині кутасні. Ий наяслэн няньніс быре. A старшей кутас шуні аркелислі: "Мый же кутали керні? Няньяс быри. Тшыглі пондал кууні ста-
..Они месяца два ходили. И они домой повернули. А немного остановились и опять охотиться стали. И у них хлеб кончился. А старший стал говорить артели: «Что же будем делать? Хлеб кончился. С голоду будем помирать теперь. Чем всем помирать с голоду, 
вен. Чел ставлі куутісьні тшыглі, вай же вӧчалей пуд. Пудбясял, кодлі усе пуд, сіе сёйні». Ная пудьясясні. Ӧкилі пуд усе, сіе виясні морттэ. Яйсэ кусэкен-кусэкен вундаласні, пӧртье пуктасні да пуні кутасні. Ий пусині кутас. A старшейислі шувасні аркелис: "Вай пе тэ первой паништлі. А гашке, пе оз шогли сёйніс?" И старшейид паништас шылтсэ. Чӧскид кажитчас. А сія оз кььь сетлі гортэдзис. Тӧваришвяс поозясні да морт яйтэ шыблаласні пӧртәясэн ий бытсэн. А гортаніс воасні, наяслэн пондас старшейис сёрнитні вӧлиськи: "Мый ешще ме эг кыь сетлі тіянлі. Ми эське лӧда-лӧднілес сёйил ставнілес. Сэтшели чӧскид морт яйис кажитчис». давайте жребий бросим. Бросим жребий, на кого жребий падёт, того и съедим». Они жребий бросили. На одного жребий пал, того человека убили. Мясо на куски порезали, в котёл положили и стали варить. И стало довариваться. А старшему говорит артель: «Давай ты хлебни. А может не годится есть?» И старший хлебнул суп. Вкусным показался. А он слова не подал до самого дома. Товарищи испугались и человечину побросали вместе с котлом. А домой вернулись, у них старший только тогда стал говорить: «Хорошо, что я вам слова не подал. Мы бы друг друга переели всех. Таким вкусным человеческое мясо показалось» (Fokos-Fuchs 1951: 342-343).

Широкое распространение этого сюжета, безусловно, свидетельствует о его важном соционормативном значении.

Считалось, что кроме промысловой удачи, житейского опыта и знания традиций, хозяин артели должен обладать также магическими способностями, «знаться» с лесными духами и духами-хозяевами зверей, поэтому часто его называли айка 'старик, хозяин', как и тунов (хозяев-хранителей места, поселения), хотя по возрасту он далеко не всегда был самым старым членом артели. В фольклоре коми существует внушительный корпус текстов о проявлении колдовских способностей айки или одиночного охотника-знахаря при отстаивании интересов 
своей артели в соперничестве с другой артелью и с его главойколдуном. Наиболее развёрнутый сюжет подобного рода записан Павлом Дорониным о противоборстве туна Паляйка из дер. Тыдор и туна Вежайка из дер. Шежам. Артель Вежайки перегнала (что само по себе уже неэтично) и расположилась по соседству с одиночным охотником Паляйкой. После того, как Вежайка насмешливо отозвался о его охотничьих способностях, Паляйка три дня приносил богатую добычу, а артель Вежайки приходила с пустыми руками. Тогда рассерженные сотоварищи Вежайки решили зарубить топорами спящего Паляйку, но Паляйка заговорил их, и они простояли с поднятыми руками всю ночь. Утром Паляйка сказал, что с этого дня удача улыбнётся артели, но и он не вернётся домой пустым. Через месяц издевательств со стороны удачливой артели Вежайки, ежедневно возвращавшийся с пустыми руками Паляйка напустил среди зимы наводнение и вынудил отдать ему половину добычи артели. Вежайка, вконец вышедший из себя, сказал: «Выпью стакан воды, и ты выйти не сможешь из избушки». Паляйка, не найдя дверей, выпил стакан воды со словами: «На дне стакана твоя смерть», чем и поставил точку в дискуссии (Му пуксьӧм 2005: 309-310).

Наделение магическими способностями опытных охотников и номинация их так же, как и колдунов-хранителей мест - $а и ̆ \kappa a$, с одной стороны, исходит из традиционного отождествления профессионала и знахаря (в контексте приравнивания профессионального знания магическому): коновал, мельник, кузнец и т. д. С другой стороны, одиночное пребывание охотника в лесу в состоянии постоянного психосоматического напряжения наедине со своими мыслями и франтазиями формировало определённый тип натурфилософра и творца, описанный Василием П. и Василием В. Налимовыми: «Именно открытость природе позволяла язычнику прислушиваться к процессам, спонтанно протекающим в подвалах сознания. Отсюда и обращение к магии - активному воздействию на стихийные силы, связывающие людей с природой, а через неё и друг с другом» (Налимов 1995: 41).

Охотничий промысел, проходивший в недеревенском, лесном пространстве в осенне-зимне-весенний период, связанный 
с большими фризическими и психологическими нагрузками и минимально обустроенным бытом, несомненно, выходил за пределы нормального течения жизни. В то же время, охота, носившая у коми сугубо товарный характер, являлась важнейшим из источников доходов в традиционном хозяйстве коми и основной сферой занятий мужчин. И поскольку, в силу указанных фракторов, настоящим мужчиной у коми считался удачливый охотник, то мальчиков с рождения ориентировали и готовили к выживанию и успешной деятельности в таёжных условиях, формируя в нём необходимые физические и духовные качества. Пройдя ряд испытаний через первые выходы в лес со старшим родственником, парень в 14 лет удостаивался чести быть принятым в артель в качестве испытуемого, после чего он уже становился "настоящим мужчиной», трудом и воспитанием в рамках традиций подготовленным к преодолению кризисных ситуаций, и твёрдо вставал на мужской жизненный путь.

\section{Примечания}

1 Зап. О. И. Уляшев 10.12.1989 в с. Нившера (Одыб) Корткеросского p-на Республики Коми от Михайловой Евдокии Андреевны, 1920 г. p.

2 Зап. О. И. Уляшев 22.08.2000 в с. Дзоль Усть-Куломского р-на Республики Коми от Логинова Кузьмы Петровича, 1930 г. p.

3 Зап. О. И. Уляшев 20.07.1984 в с. Вольдино (Вӧльдін) Усть-Куломского p-на Республики Коми от Уляшева Семёна Николаевича, 1912 г. p.

4 Зап. О. И. Уляшев 21.06.2001 в с. Вольдино Усть-Куломского р-на Республики Коми от Уляшева Петра Никитича, 1952 г. p.

5 Зап. О. И. Уляшев 16.06.1988 в с. Вольдино Усть-Куломского р-на Республики Коми от Уляшева Ивана Никитича, 1939 г. р.

6 Зап. О. И. Уляшев 16.06.1988 в с. Вольдино Усть-Куломского р-на Республики Коми от Уляшева Ивана Никитича, 1939 г. р.

7 Зап. О. И. Уляшев 16.06.1988 в с. Вольдино Усть-Куломского р-на Республики Коми от Уляшева Ивана Никитича, 1939 г. р.

8 Зап. О. И. Уляшев 07.07.2006 в дер. Бадьёльск (Бадьёль) УстьКуломского р-на Республики Коми от Уляшева Евгения Егоровича, 1927 г. p. 
9 Зап. О. И. Уляшев 07.07.2006 в дер. Бадьёльск Усть-Куломского р-на Республики Коми от Уляшева Евгения Егоровича, 1927 г. p. Текст приводится в дословном переводе автора.

10 Зап. О. И. Уляшев 20.06.1990 в с. Вольдино Усть-Куломского р-на Республики Коми от Уляшева Никиты Егоровича, 1910 г. p.

11 Зап. О. И. Уляшев 12.08.2007 в с. Приуральское (Приуральскӧй) Троицко-Печорского р-на Республики Коми от Уляшева Михаила Ивановича, 1960 г. р.

12 Зап. О. И. Уляшев 07.07.2006 в дер. Бадьёльск Усть-Куломского р-на Республики Коми от Уляшева Евгения Егоровича, 1927 г. p. Текст приводится в дословном переводе автора.

13 Зап. О. И. Уляшев 10.07.1991 в с. Вольдино Усть-Куломского р-на Республики Коми от Уляшева Ивана Никитича, 1939 г. р.

14 Зап. О. И. Уляшев 10.12.1989 в с. Нившера Корткеросского р-на Республики Коми от Габовой Александры Степановны, 1933 г. р.

${ }^{15}$ Во-первых, священнику не позволял охотиться сан, и он (подобно женщинам) питался готовой дичью, пожертвованной церкви. Вовторых, он носил длинную одежду и не стриг волосы, что также не отвечало традиционным представлениям о маскулинности, поскольку длинные волосы и одежда являлись атрибутами женщин и юродивых. Фемининность христианских священников, в определённой мере, исходила также из "солярности» служителей Христа и женщин и «лунарности» представителей язычества и мужчин (об «общей судьбе лам и женщин» у тувинцев см. Дьяконова 1960: 257).

16 Зап. О. И. Уляшев 20.06.1990 в с. Вольдино Усть-Куломского р-на Республики Коми от Уляшева Никиты Егоровича, 1910 г. p.

\section{Литература}

Дьяконова, Валентина 1960. Материалы по одежде тувинцев (По полевым материалам 1958 г.). - Труды тувинской колплексной археолого-этнографбиеской экспедиции. Т. 1. Материалы по археологии и этнографии Западной Тувы. Москва-Ленинград. 
КМ 1991 = Рочев, Юрий (сост.) Коми мойдбяс [Коми сказки]. Сыктывкар.

КМС 1963 = Плесовский, Фёдор (сост.). Коми мойдъяс да сьылланкывъяс [Коми песни и сказки]. Сыктывкар.

Коми морт 1928 = Очерки зырянской охоты. - Записки Общества изучения Коли края. Вып. I. 81-82.

Конаков, Николай 1983. Коли охотники и рыболовы во второй половине XIX - начале XX в. Культура промыслового населения таёжной зоны Европейского Северо-Востока. Москва: Наука.

Конаков, Николай 1994. Этнопедагогика коми. - Традииионная культура коми. Этнографбческие очерки. Сыктывкар: Коми книжное издательство, 118-122.

Микушев, Анатолий 1969. Коли эпические песни и балладь. Ленинград: Наука.

Му пуксьӧм 2005 = Лимеров, Павел (ред. \& сост.). Му пуксьӧм Сотворение мира. Устная мифбологическая проза народа коми. Сыктывкар.

Налимов, Василий В. 1995. Реальность нереального. Вероятностная модель бессознательного. Москва.

Налимов, Василий П. 1903. Некоторые черты из языческого миросозерцания зырян. - Этнографическое обозрение. № 2. 77-86.

Налимов, Василий П. 1991. К вопросу о первоначальных отношениях полов у зырян. Семья и социальная организаиия фбинно-угорских народов. Труды Института языка, литературы и истории Коми НЦ УрО РАН. Вып. 49. Сыктывкар, 3-12.

Панюков, Анатолий 2014. Из детской промысловой магии коми-зырян. Традииионная культура: Научный альманах. № 3. 146-156.

Серов, Николай 2002. Светоиветовая терапия. Сльсл и значение ивета: инфорлация - ивет - интеллект. Санкт-Петербург.

ФНК 1938 = Попов, Александр (сост.) Фольклор народа коли. Архангельск. 
ЭУМ 1999 = Сиикала, Анна-Леена \& Напольских, Владимир \& Хоппал, Михай (ред.). Энииклопедия уральских мифбологий. Т. 1. Мифология коми. Москва: ДиК.

Fokos-Fuchs, David 1951. Volksdichtung der Komi (Zyrjänen). Budapest: Akadémia Kiadó. 


\section{ФОЛЬКЛОРИСТИКА КОМИ: исследования и материалы}

\section{http://www.folklore.ee/rl/pubte/ee/sator/sator17/}

ISSN 1736-0323

ISBN 978-9949-586-24-0

DOI: $10.7592 /$ Sator.2016.17

Тарту 2016

Авторы: Ирина Ильина, Юлия Крашенинникова, Павел Лимеров, Людмила Лобанова, Светлана Низовцева, Алексей Рассыхаев, Анатолий Панюков, Галина Савельева,

Олег Уляшев

Редактор серии: Маре Кыйва

Редакторы-составители выпуска: Людмила Лобанова \& Николай Кузнецов

Оформление обложки: Анатолий Панюков \& Андрес Куперьянов

Верстка \& HTML: Диана Кахре

Печатное издание: ФОЛЬКЛОРИСТИКА КОМИ: исследования и материалы. SATOR 17. Тарту 2016

Составление, техническое оформление и печать книги осуществлены при поддержке Эстонского институционального исследовательского гранта 22-5 (Религиозные и нарративные аспекты фольклора).

Оформление электронного издания осуществлено при поддержке проекта ЕККМ14-344 “Расширение областей применения и представление эстонского языка, культуры и фольклора в электронных информационных средствах".

(с) EKM Teaduskirjastus / Научное издательство ЭЛМ

(c) Авторы

(с) Анатолий Панюков \& Андрес Куперьянов 